\title{
John Rawls's Concept of Justice as Fairness
}

\author{
Edor J. Edor \\ Department of Philosophy, University of Calabar, Nigeria. \\ Email: edorjedor@unical.edu.ng
}

(Received: May-2020; Reviewed: July-2020; Accepted: July-2020;

Avalaible Online: July-2020; Published: September-2020)

c) (7) (8) This is an open access article distributed under the Creative Commons Attribution License CC-BY-NC-4.0 (2020 by author (https://creativecommons.org/licenses/by-nc/4.0/)

\begin{abstract}
John Rawls's theory of Justice is one of the most influential conceptions of justice. Scholars have continued to study it to understand the principles in the formation and to further frame it in the context of contemporary situations. This paper contributes to the ongoing discussion by presenting Rawls' concept of "justice as fairness" as it evolved from the traditional conception of justice to the modern-shift in the concept. The paper also examines Rawls's concept of justice as fairness, and it focuses on analyzing or studying the concept of justice as fairness in terms of the principles used in its formulations. Several criticisms developed by political philosophers to critique the idea were examined. In conclusion, it was argued that Rawls's invention of the veil-of-ignorance for the original position has affected the theory negatively.
\end{abstract}

Keywords: Justice; fairness; right; duty; social ontology; inequality; equality; original position; good; bad; virtue.

\section{INTRODUCTION}

Philosophers, since ancient times, have continued to tinker on the notion of justice. And their formulations of the concept of justice have been influenced by the principles of the governmental system in vogue at the various epochs (Brian 2019, pp. 614). As a result, the modern view of justice has evolved from its traditional conceptions. The traditional concept of justice focused on the just man, that is, it was concerned with the development of a virtuous man. The modern concept of justice focused on a just society, that is, it is concerned with the allocation of resources. Traditional views approached the concept of justice from a metaphysical angle, while modern views seem to approach it from a political perspective. John Rawls is one of the modern political philosophers who has significantly influenced the modern view of justice. His concept of justice as fairness reinforces the modern view and presents a formulation 
of justice as a devise to protect the individual liberties of all citizens and as a framework for the allocation of benefits and burdens.

John Rawls presented his view of justice in the book A Theory of Justice published in 1971. Since then, philosophers and various scholars started discussing his ideas to understand the principles in the formulation and to critique its social detailing. This paper contributes to the ongoing discussion by presenting Rawls' concept of "justice as fairness" as it evolved from the traditional conception of justice to the modern shift in the concept. Also, the criticisms developed by political philosophers to critique Rawls' idea of justice are considered.

\section{THE CONCEPT OF JUSTICE: A BRIEF HISTORICAL REVIEW}

What is justice? This question has agitated the minds of philosophers since time immemorial. Various conceptions and doctrines have been formulated and developed in pursuit of crafting a correct concept of justice. Generally, the formulation of the concept of justice differs between traditional and modern epochs. In the traditional and modern epochs, the concept of justice is concerned with the development of a just man. To this end, the concept of justice took the dimension of psychology and metaphysics. Under it, the question of justice focused on a moral, good and virtuous person. The idea was that since it is the individuals that constitute the society, political philosophy should focus on grooming the best characters in individuals (Wolfe \& Jonathan 2018, pp. 332). Once the virtuous persons are evolved, and they are called to man social institutions, they would act justly. Moreover, a society of virtuous people would employ virtues in their associations and interactions. As Gauba rightly observes, justice in traditional views focused on preparing individuals to perform the duties attached to their statuses as determined by law, customs and tradition (2003, pp. 374).

Plato was one of the philosophers who held this view. In his foremost book, Republic, Plato argued that justice constitutes individual virtue (1997, pp. 142). This implies that members of a society should perform their duty to society in accordance with their ontological placements in it (Plato 1997, pp. 142). Plato focused on answering the question "what sort of person should I be?" by averring that a just person is he whose desires are governed by reason (1997, pp. 143). Stephen Watt (1997) notes that in his information of the concept of justice "Plato tries to move his audience to an understanding that a good life consists in being a certain sort of action: from an act-centered morality where the primary question is "what should I do? to an agent-centered morality where the primary question is "what sort of person should I be?" This attempt at paradigm shift was a reaction/response to the conventional assumption held among Plato's contemporaries that justice consisted in performing actions regardless of the moral character of the person who acts. Plato reasoned that justice is personal (Kogelmann 2017, pp. 667), in conjunction with his ontological placement in society. Confucius shared a similar view of justice. For him, justice constitutes the rectification of names and honouring of obligations (Chunpo \& Jialong. 562-563). What this means is that everyone in the society is under one obligation or the other in the society according to law, customs and conventions; hence justice involves honouring one's obligations to the later without attempting to disrupt the order of things by jumping board or abandoning one's duty post.

I shall note in passing that this conception can stifle liberty and creativity; individuals are fixed to particular positions and denied the motivation to improve upon what they inherited. Persons under this kind of justice have no choice and say in the society that they live or in the 
institutions that they work but only to obey commands and maintain line regiment as mechanical as possible. Hence, eye-service could not be the order of the day in such a society.

Aristotle maintained the same line of reasoning as Plato but with slight modifications. Like Plato, he saw justice as virtue and justice as answering the question of "what sort of person should I be". According to him, "justice is perfect virtue... because its possessor can practice his virtue towards others" (Aristotle 1996, pp. 155). He also averred that "justice... is not a part of virtue but the whole of virtue" (Aristotle, 1996, pp. 115). What Aristotle was saying is that a just person is he who acts virtuously, particularly in relation to others. Aristotle also argued that justice refers to fairness that the just refers to "that which is lawful and that which is equal or fair" (Aristotle, 1996, pp. 114). This should be understood within the context of the mean. Justice as that which is "lawful" is discussed in the sense of the station-fixed morality of Plato and Confucius. Justice as that which is "fair" is further distilled in the Golden Mean. For him justice should be understood as the mean between good and evil- hence injustice means "taking too much of good things and too little of bad things" (Aristotle, 1996, pp. 114). Justiceunderstood within the context of the mean, presupposes the existence of equality rather than proportionality. Equity must precede justice. The principle of equality or proportionality allows the mean to be determined justly (Aristotle, 1996, pp. 118-9).

At this point, Aristotle's concept of justice took up the character of distributiveness. To this end, justice refers to taking one's due and justice involves exceeding your due. What is just is that which is proportionate: "unjust is that which violates proportion" (Aristotle 1996, pp. 119). Aristotle had examined the various strands of justice - political, corrective, rectificatory and distributive justice - but all of them boil down to the same meaning or qualification of justice as fairness or proportionality based on the principle of the mean. The goal of justice, for him, is to produce and preserve happiness within the political community (Aristotle 1996, pp. 114-5). This was the disposition discourse on justice took in the traditional setting.

In the modern epoch, the character of the discourse has altered to focus on just society rather than just individuals. The traditional concept of justice also aimed to produce a just society but by producing just individuals to populate society. In the modern epoch, the concept of a just society is determined in terms of resource allocation. In other words, the modern conception of justice concerns with who gets what, how and why. This means that the modern conception of justice is primary distributive. I shall discuss two leading traditions that characterized the epoch. These include utilitarianism and Marxism.

Utilitarianism is a political doctrine represented by Jeremy Bentham and John Stuart Mill, although discussions involving the idea had been ongoing even before them. Utilitarianism is the principle which "holds that actions are right in proportion as they tend to promote happiness, wrong as they tend to produce the reverse of happiness" (Mill 1994, pp. 371). The focus of utilitarianism is the just distribution of happiness which Aristotle said is the virtue of justice. Aristotle had stated that 'in one of its senses the term 'just' is applied to anything that produces and preserves the happiness, or the component parts of the happiness, of the political community" (1996, pp. 114-5). Utilitarianism holds that justice is concerned with creating the greatest happiness for the greatest number of people. In other words, happiness or pleasure is the good of moral virtue. Every individual is manifestly aiming to live a happy or pleasurable life. Justice, therefore, consists of helping people to achieve this goal of pleasure.

To actualize this goal, utilitarianism formulates the justice concept on the principles of equality, liberty and utility. The principle of equality provides everyone with equal access to the opportunity to be happy. The principle is further tied to the principle of liberty which maintains 
that everyone considered equally must be free to pursue and achieve happiness or pleasure within the constraint of law. The principle of utility enables us the weighing of actions and intentions to determine its harm/pain and pleasure/happiness values, which determines the course upon which the right action must take. Generally, I shall note that utilitarianism is a majoritarian principle whose focus is the happiness of the majority at the expense of the minority in the society.

Marx's principle of justice is definitely formulated in the Critique of the Gotha Program. In the Gotha Program, Marx formulated his principle of justice as distributive. For Marx, a just society is that which satisfies the needs of all irrespective of social class. It is a society where equality of all people is upheld, and of which the modes of production are collectively owned. Marx's conception of justice can be summarized in his maxim: from all according to their abilities, to all according to their needs. This is Marx's principle of distributive justice which would characterize post-capitalist society (Marx 1922, pp. 29). It is important to recognize that Marx rejected the applications of the proportionality principle of justice in the communist society because it favours those who are gifted by nature while it discounts the handicaps and the ungifted (Marx 1922, pp. 31). This was unjust distribution. To this end, Marx argues that a just society is that which satisfies the needs of all irrespective of social status.

Marx's conception of justice coincides with the conception of justice in socialism. Ludwig von Mises avers that 'socialism is nothing but a theory of just distribution" (1922, pp. 151). The principle of distributive justice holds that people should be treated justly in their relation to other people as well as institutions. It is seeing to it that people receive that which they are entitled based on the egalitarian principle and right recognition (Muson, 776). For the socialist a just society is that which satisfies the need of all irrespective of social status. It is a society where equality of all people is upheld, and which modes of production are collectively owned. There are four principles or elements upon which socialist distribution is based: equal distribution per head, distribution according to service rendered to the community, distribution according to needs, and distribution according to merits (Mises, 1962, pp. 155).

This section indicates the various views of justice before the development of the concept of justice as fairness by Rawls. It should be noted that these ancestor-views, as we shall see, have contributed to influencing the formulation of justice as fairness. The views elaborated here are not in any way definite or determinate but they generally reflect two major divides in the conception of justice in the history of political philosophy.

\section{JUSTICE AS FAIRNESS}

According to Gauba, "the main problem of social justice is to decide an appropriate allocation of the advantages that are available or that can be secured through the instrumentality of the social organization" (2003, pp 375). This statement summarizes Rawls' point of departure in the formulation of his concept of justice as fairness. Rawls saw political philosophy as an activity contrived to determine the allocation of benefits and burdens in society. In this direction, political philosophy is concerned with who gets what, how and why. In one of his earliest essays, Justice as Fairness, published in April 1958, Rawls opined that "the principles of justice are regarded as formulating restrictions as to how practices (social institutions) may define position and offices, and assign thereto power and liabilities, rights and duties" (1985c, pp. 164). He also stated that "justice is not to be confused with an all-inclusive vision of a good society, it is only one part of any such conception" (1985c, pp. 165). In other words, a just 
society cannot be summarily declared as good and a good society cannot be summarily declared as just. These are completely different concepts. This position rails against the view of Aristotle who held that "justice...is not a part of virtue (good) but the whole of virtue" (Aristotle, 1996, pp. 115).

Rawls also maintained that justice cannot be summarized merely as distributive without taking its wider connections into account, "we cannot, in general, assess a conception of justice by its distributive role alone, however useful this role may be in identifying the concept of justice, we must take into account its wider connections" (Rawls 1999, pp. 6). This also rails against the position of the socialists who summarily define justice merely as the principle of distribution. Rawls argued that although many different things can be said to be just and unjust, his concept of justice as fairness is based on the idea that "the primary subject of justice is the basic structure of society, or more exactly, how the major social institutions distribute fundamental rights and duties and determine the division of advantages from social cooperation" (Rawls 1985a, pp. 6). To this end, Rawls said by the concept of justice he takes to be defined by the role of its principles in assigning rights and duties and defining the appropriate division of social advantages (Rawls 1985a, pp. 9).

So far we can see that Rawls's conception of justice takes the character of the modern conception of justice, which is designed to concern with a just society in terms of allocations of benefits and burdens, rights and duties. But Rawls warned that his concept of justice as fairness "is intended as a political conception of justice" that can be applied to "the basic structure of a modern constitutional democracy" (Rawls 1985b, pp. 224). He stressed that "justice as fairness is not intended as the application of a general moral conception to the basic structure of society" (Rawls 1985b, pp. 225). That is to say, the concept of justice as fairness taken outside its context in modern constitutional democratic structure will lose its meaning.

In consideration of the views expressed above, Rawls formulated the concept of "justice as fairness" in the form of two principles stated as follows:

First: each person is to have an equal right to the most extensive of equal basic liberties compatible with a similar scheme of liberties for others.

Second: social and economic inequalities are to be arranged so that they are both (a) reasonable expected to be to everyone's advantages, and (b) attached to positions and offices open to all (Rawl 1989, pp. 53).

The principles were later revised in Rawls last published work as follows:

a) Each person has the same indefeasible claim to a fully adequate scheme of equal basic liberties, which scheme is compatible with the same scheme of liabilities for all; and

b) Social and economic inequalities are to satisfy two conditions: first, they are to be attached to offices and positions open to all under conditions of fair equality of opportunity; and second, they are to be to the greatest benefit of the least-advantaged members of society (the difference principle) (Restatement, 42-43).

Rawls noted that the revision in the second principle are "merely stylistic" whereas the revision in the first principles are "significant". He stated that:

Each of these principles applied to a different part of the basic structure; and both are concerned not only with basic rights, liberties, and opportunities but also with the claim of equality; while the second part of the second principle underwrites the worth of these institutional guarantees. The two principles together, when the first is given priority over the second, regulate the basic institutions which realize these values. (Rawls 1985b, pp. 228). 
Rawls maintained that the first principle holds priority to the second; and that in the second principle fair equality of opportunity holds priority over the difference principles (Restatement, 43). This means that in applying the principles the prior principles are to be fully satisfied ahead of any other they are expressed in the revised theory. Further, he averred that the first principle covers the constitutional essentials; the second principle requires a fair quality of opportunity and social and economic inequalities be governed by the difference principle (restatement, 47). Rawls also stated that by "fair equality of opportunity" he means not merely that public office and social position be open in the formal sense, but that all should have a fair chance to attain them (Restatement, 43). For example, as James Nickel argues, people should be provided with free education in order to prepare them to participate in social institutions (2009, pp. 441). Moreover, people should not be excluded from the opportunity based on the social class to which they are born. Rawls argued that "citizens do not join society voluntarily but are born into it", moreover, citizens are free and equal persons (Rawls 1985b, pp. 233). Further, Rawls maintained:

The first requires equality in the assignment of basic rights and duties, while the second holds that social and economic inequalities, for example, inequalities of wealth and authority, are just only if they result in compensating benefits for everyone, and in particularfor the least advantaged members of society (Rawl, 1985a, pp. 13).

This position clearly rules out the majoritarian logic of utilitarianism which justifies the unhappiness of some on the ground that a large majority are happy. As Rawls argues, "it may be expedient but it not just that some should have less so that others may prosper (Rawl, 1985, pp. 13).

\section{RAWLS ON FAIRNESS}

It is important to state that an understanding of Rawls's conception of 'fairness' is crucial, or perhaps, pre-requisite to sound or holistic comprehension of his theory of justice. Justice as fairness rests on few basic assumptions that "society [is] a fair system of cooperation between free and equal persons" (Rawls 1985b, pp. 231). That the basic structure of society is that there exist social inequalities that are beyond the rational decisions of the individual in it. That the person has needs of which their meet is to be derived from society. Rawls argued that "citizens do not join society voluntary but are born into it", yet they are free and equal persons (Rawls 1985b, pp., 233). However, such a society would agree on a framework for social cooperation. Whatever framework or principles they agree on would "specify the kinds of social cooperation that can be entered into and the form of government that can be established" (Rawls 1985a, pp. 10). Rawls averred that the principle they would eventually agreed upon would be fair and just. Hence, he called these principles "justice as fairness". Rawls opined that the principles they would agree upon would be as follows:

(a) Each person has the same indefeasible claim to a fully adequate scheme of equal basic liberties, which scheme is compatible with the same of liberties for all; and

(b) Social and economic inequalities are to satisfy two conditions: first, they are to be attached to office and positions open to all under conditions of fair equality of opportunity; and second, they are to be to the greatest benefit of the least-advantaged members of society (the difference principle) (Restatement,42-43).

A social institution is fair or just when it satisfies these principles which those participating in it could propose to one another for mutual acceptance. 
Rawls maintained that "justice as fairness starts from the idea that is to be conceived as a fair system of social cooperation" (Corlett 2020, pp. 2). This means that the notion of fairness in the conception of justice as fairness is only properly meaningful within the context of the concept of social cooperation the basis of equality and liberty. The concept of cooperation which defines Rawls' notion of fairness can be understood by its three specific elements. The three specify an element that defines the concept of cooperation adopted by Rawls are as follows: one, cooperation is guided by publicly recognized rules which those cooperating accept as properly regulating their conduct, and is distinct from activity coordinated by an order issued by a central authority; two, cooperation involves fair terms of cooperation, including basic rights and duties, which each and all participant(s) reasonably and mutually accept(s); and three, cooperation requires each and all participants the rational advantage in terms of the good they want to achieve when viewed from their own standpoint (Rawls 1985b, pp. 232). Rawls averred that the public conception of justice should be characterized by the fair terms of social cooperation (Rawls 1985b, pp. 233). He maintained that the fundamental question of political justice is "what is the most appropriate conception of justice for specifying the terms of social cooperation between citizens regarded as free and equal persons" (Rawls 1985b, pp. 234). The pursuit of this question led Rawls to the idea of justice as fairness.

\section{THE ORIGINAL POSITION}

The idea of the original position is introduced to work out the conditions under which justice as fairness can evolve, and specify the most appropriate principle for realizing liberty and equality once the society is viewed as a system of cooperation between free and equal persons. Rawls stated that "justice as fairness recast the doctrine of the social contrast" (Rawls 1985b, pp. 235). In it, the social contract theories of Locke, Rosseau and Kant are taken to a higher level of abstraction in its generalization of a conception of justice. Rawls held that "in justice as fairness the original position of equality corresponds to the state of nature in the traditional theory of the social contrast" (Rawls 1999, pp. 11). But the social contractarian method adopted by Rawls does not lead the original position to mean one in which people enter into a particular society or set up a particular form of government. Rawls had argued that "citizens do not join society voluntarily but are born into it" (Rawls 1985b, pp. 233). Rather, the significance of the original position is to serve as a device of representation in a hypothetical condition that is fair. In the original position, "men are to decide in advance how they are to regulate their claims against one another and what is to be the foundation charter of their society" (Rawl, 1985a, pp. 10). In the original position, participants in social cooperation choose together, and in one joint act, the principles under which to assign basic rights and duties and to determine the decision of social benefits; in order to ensure that no one is advantaged or disadvantaged on the ground of natural chance or the contingency of social circumstances.

The original position is, one might say, the appropriate initial status quo, and thus the fundamental agreements reached in it are fair. This explains the property of the name "justice as fairness"; it conveys the idea that the principles of justice are agreed to in an initial situation that is fair (Rawl, 1985a, pp. 11).

Rawls stated that "in justice as fairness the original position of equality corresponds to the state of nature in the traditional theory of the social contract" (Rawl, 1985a, pp. 11). The original position is understood as a purely hypothetical situation characterized in such a way that it could lead to a certain conception of justice. Some of the characteristics of the situation in 
the original position is that "no one knows his place in society, his class position or social status, nor does anyone know his fortune in the distribution of natural assets and abilities, his intelligence, strength, and the like" (Rawls 1999, pp. 11). In other words, the people in the original position are free, equal and rational. Not that the people in the original position are equal in class, position, social status, intelligence, strength, abilities, and capacities as they may be naturally endowed perchance or conferred upon by the contingency of social circumstances; but that they are not allowed to know these properties that they possess in them and in others. This situation is expressed figuratively by saying that the parties are behind a veil of ignorance (Doughty 2019, pp. 7). Generally, the original position is simply a "device of representation" that describes a situation, of reaching an agreement of social cooperation, which is fair (Cruz e Silva, 2019, pp 452). Once a situation, for a conception of justice, prevents the reliance on natural endowments and the contingencies of social circumstance in a quest for political and economic advantage, it will lead to these principles of justice as fairness: the first requiring equality in the assignment of basic rights and duties, and the second upholding social and economic inequalities as just only if they result in compensating benefits for all, particularly the least advantaged members of society (Rawls 1999, pp. 13 - 4).

\section{A CRITIQUE}

Rawls's ideas have been praised as ambitious and progressive. However, some scholars have raised several criticisms against it. Some have criticized the original position as being artificial. Some disagree with the content and scope of social goods. Others criticize the conception of a person in the theory. Other criticisms have been raised by economic and political philosophers, but here I want to focus on what I consider as the most fundamental defect in the theorization and conception of justice as fairness. There are two of them: the first has to do with the inordinate ordering and prioritization of the principles, and the second has to do with the problem created as a result of conceiving the primary goods behind a veil of ignorance. In this paper, I want to focus on the latter.

Rawls had argued that justice as fairness is a social framework for fair distribution of liberty, opportunity, income, wealth and the social bases of self-respect (Rawl, 1985a, pp. 54). He argued that these are the primary goods because of their connection with the basic structure, and particularly they are things a rational man would want more than all else for the framing and the execution of a rational plan of life (Rawl, 1985b, pp. $79 \& 347$ ). Hence, "the persons in the original position are assumed to accept this conception of the good ... [as] they evaluate the conceptions of justice available to them in the original position" (Rawl, 1985a, pp. 380). In other words, persons in the original position are said to have adopted the concept of justice as fairness in pursuance of the afore-mentioned primary goods.

Firstly, I note that Rawls's conception of the good is excessively materialistic; and seems designed according to the American Dream of materialism. Secondly, Rawls' conception of the "rational" is defective because it seems to derive from a person's recognition of his (Rawls's) list of primary goods as valid. Now, taking departures from these two observations, I want to note that the "veil of ignorance" in the original position created two problems: first, it denied the persons in the original position the essential ingredient - social ontology - in the understanding of the good, and second, it created what I may call 'paradigm-crossing problem'. For me, these are the most fundamental issues with Rawls' theory of justice; and it has to do with the very foundation of the theory itself. The veil of ignorance was excessive baggage and has created a 
very serious complication that prevents Rawls lofty ideas to cross from the realm of utopia to the region of human social and political needs. Let me turn to explain these observations I have made.

First, Rawls' conception of the good is explained in Chapter VII of his book A Theory of Justice. It views the good as a mechanical need that is based on a purely materialistic foundation, to the relegate attention of the non-materialistic. His conception of good is defined in terms of opulence and welfare, based on the Aristotelian notion of good as happiness. Based on this viewpoint, Rawls assumed that the persons in the original position would accept this conception.

Except that all the persons in the original position were Americans or some material bigots; their understanding and conception of the good lack the essential ingredient necessary in the conception of the good. This essential ingredient is social ontology. One's conception of good cannot be independent of the bias of social ontology. Even 'universally accepted goods' lose meaning, and sometimes got rejected, once they are taken out of social and cultural contexts. Some positive goods can, and do, become negative values or undesirable once they cross-cultural and social boundaries. With this viewpoint in mind, I argue that some of Rawls's primary goods can be rejected outrightly in some cultures of the East and Africa. I shall label such goods as 'controversial values'.

Let me limit the list of the controversial values to income and wealth; although other primary goods are controversial without their social ontology. The pursuit of income and material wealth are not valid primary goods to persons in Asian and African cultural ontologies (Sen, 1997, pp. 393; Nyere, 1987, pp. 4-5). Therefore, I wonder if the veil of ignorance covered the Americans in the original position. Indeed, for the people in the original position to choose a valid concept of justice they did not need to be under the veil of ignorance. Once, they came under the veil of ignorance they became what Amartya Sen called "rational fools", and therefore no longer able to choose rationally.

Secondly, the veil of ignorance created what I call the 'paradigm-crossing problem'. Persons in the original position are denied knowledge of their social characteristics. The purpose is that they may act from a socially neutral position. In other words, the persons in the original position are brought under a veil of ignorance to become a person of equals so that their actions may be fair. Rawls thought that whenever people are recognized as equals their collective action will be fair therefore just. The issue is that these persons were only under because they were fools. The persons in the original position are equals only under a certain unrealistic situation that is temporary. The veil of ignorance was not to remain there forever; the persons in the original position were brought under the veil of ignorance primarily to adopt a conception of justice. After adopting a conception of justice, the veil of ignorance was to be removed or they were to go back to their various social ontologies. At that point, a problem would occur.

When the veil of ignorance is removed, the participants in the original position would no longer recognize the primary goods as those they adopted to pursue. Some of them would argue that if they ever adopted those primary goods as worthy of pursuit then they did so without their senses. Indeed, the persons in the original position were more or less like slaves. The persons in the original position, once the veil of ignorance is removed, would no longer accept the conception of justice they adopted because the primary good, which was to be realized under the framework of justice as fairness, is only made meaningful within the social ontology. This is what I call a 'paradigm-crossing problem'. The problem is that once the persons in the original position cross over from the paradigm of social ignorance to the paradigm of social ontology 
Volume 4, Issue 1, September, 2020 Page. 179-190

(their cultural context) their views and conceptions of the primary goods would alter or change in favour of the cultural conception of good. To this end, Rawls' conception of justice as fairness is merely a utopian device that cannot function in the real world.

\section{CONCLUSION}

This study began with a brief historical review of the concept of justice, starting from Plato. This was followed by an examination of Rawls' concept of "justice as fairness". From the analysis, it is evident that Rawls' theory set out to address a fundamental problem of society, namely, inequality. To achieve this, he developed certain principles of justice to transform the social and economic inequalities into beneficial inconveniencies. However, it has been pointed out in this paper that Rawls' conceptual framework has suffered major defects occasioned by the veil of ignorance. The paper concludes that although the theory is lofty and interesting, its usefulness has been complicated or undermined by the veil of ignorance.

\section{REFERENCES}

Aristotle. (1996). The Nicomachean Ethics.Trans. Harris Rackham.Hertfordshine: Wordsworth editions Limited.

Brian K. (2019). Kant, Rawls, and the Possibility of Autonomy.Social Theory and Practice, 45 (4), 2019, pp. 613-35, doi:10.5840/soctheorpract2019123173.

Corlett, J. A. (2020). John Rawls' Theory of Intergenerational Justice. Encyclopedia of Business and Professional Ethics, pp. 1-3, doi: 10.1007/978-3-319-23514-1_1173-1.

Cruz e Silva, V. (2019). John Rawls' 'justice as Fairness' and the Demandingness Problem. ActaScientiarum. Human and Social Sciences, 41(1).

Doughty, H. A. (2019). John Rawls and the Evolution of Liberalism. Innovation Journal, 24(3), $1-29$.

Gauba, O. P. (2003). An introduction to Political Theory. $4^{\text {th }}$ ed. Delhi: Macmillan India Ltd.

Kogelmann, B. (2017). Justice, Diversity, and the Well-Ordered Society. Philosophical Quarterly, 67(269), 663-84, doi:10.1093/pq/pqw082.

Marx, K. (1922). The Gotha Program. New York: Socialist Labor Party.

Mill, J. S. (1994). "Utilitarian." Fifty Readings in Philosophy. Ed. Donald C. Abel. New York: McGraw-Hill, Inc, 371-379.

Mises, L. (1962). Socialism: An Economic and Sociological Analysis. Trans. J. Kahane. New Haven: Yale University Press.

Nickel, J. W. (2009). "A Defense of Welfare Rights as Human Rights". Contemporary Debates in Political Philosophy. Ed. Thomas Christiano \& John Christman. Oxford: Blackwell Publishing Ltd, 2009. 437-456.

Nyerere, J. K. (1987). "Ujamaa - The Basis of African Socialism". The Journal of Pan African Studies, 1(1).

Plato. (1997). Republic. Trans. John Llewellyn Davies \& David James Vaughan. Hertfordshire: Wordsworth editions Limited.

Rawls, J. (1985a). "Justice as Fairness". The Philosophical Review, 67(2), 164-194.

Rawls, J. (1985b). "Justice as Fairness". The Political not Metaphysical. Philosophy and Public Affairs, 14(3), 223-251

Rawls, J. (1999). A Theory of Justice (Revised Edition). Massachusetts: Harvard University Press. 
Rawls, J. (1985c). Justice as Fairness: A Restatement. Ed. Erin Kelly. Massachusetts: Harvard University Press, 2001.

Sen, A. K. (1997). "From Income Inequality to Economic Inequality."South Economic Journal, 64(2), 384-401.

Watt, S. (1997). "Introduction". Republic. Trans. John Llewelyn Davies \& David James Vaughan. Hertfordshire: Wordsworth editions Limited.

Wolfe, C. J., \& Jonathan S. J. P. (2018). “A Response to John Rawls's Critique of Loyola on the Human Good." International Philosophical Quarterly, 58(3). 
190 | Pinisi Discretion Review

Volume 4, Issue 1, September, 2020 Page. 179-19o 